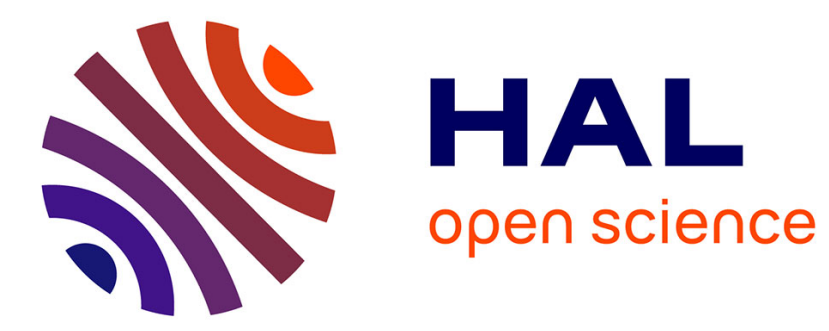

\title{
Experimental Study of tool Wear Mechanisms in Conventional and High Pressure Coolant Assisted Machining of Titanium Alloy Ti17
}

\author{
Yessine Ayed, Guénaël Germain, Amine Ammar, Benoit Furet
}

\section{To cite this version:}

Yessine Ayed, Guénaël Germain, Amine Ammar, Benoit Furet. Experimental Study of tool Wear Mechanisms in Conventional and High Pressure Coolant Assisted Machining of Titanium Alloy Ti17. Key Engineering Materials, 2013, 554-557, pp.1961-1966. 10.4028/www.scientific.net/KEM.554557.1961 . hal-01195928

\section{HAL Id: hal-01195928 \\ https://hal.science/hal-01195928}

Submitted on 8 Sep 2015

HAL is a multi-disciplinary open access archive for the deposit and dissemination of scientific research documents, whether they are published or not. The documents may come from teaching and research institutions in France or abroad, or from public or private research centers.
L'archive ouverte pluridisciplinaire HAL, est destinée au dépôt et à la diffusion de documents scientifiques de niveau recherche, publiés ou non, émanant des établissements d'enseignement et de recherche français ou étrangers, des laboratoires publics ou privés. 


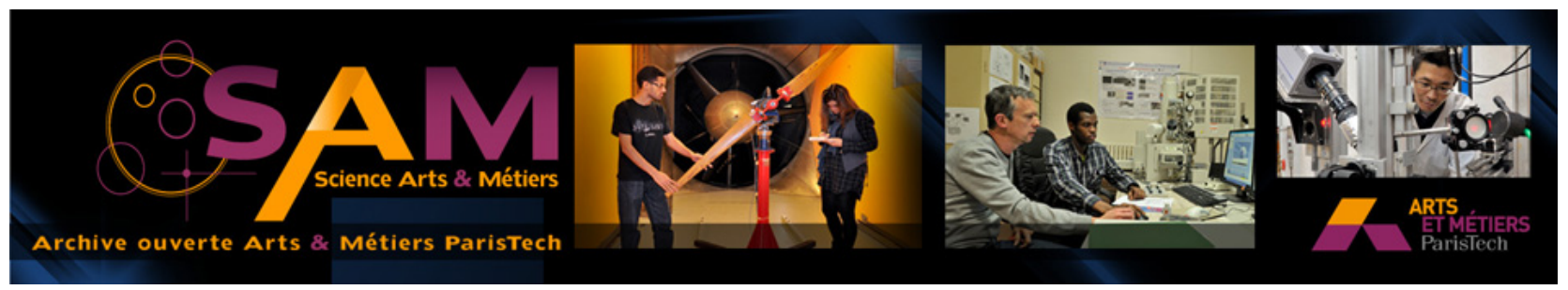

Science Arts \& Métiers (SAM)

is an open access repository that collects the work of Arts et Métiers ParisTech researchers and makes it freely available over the web where possible.

This is an author-deposited version published in: http://sam.ensam.eu

Handle ID: .http://hdl.handle.net/10985/9959

\section{To cite this version :}

Yessine AYED, Guénaël GERMAIN, Amine AMMAR, Benoit FURET - Experimental Study of tool Wear Mechanisms in Conventional and High Pressure Coolant Assisted Machining of Titanium Alloy Ti17 - Key Engineering Materials - Vol. 554-557, p.1961-1966 - 2013 


\title{
Experimental study of tool wear mechanisms in conventional and high pressure coolant assisted machining of titanium alloy Ti17
}

\author{
Yessine AYED ${ }^{1, \text { a }}$, Guenael GERMAIN ${ }^{1, b}$, Amine AMMAR ${ }^{1, c}$ \\ and Benoit FURET ${ }^{2, d}$
}

\author{
${ }^{1}$ Arts et Métiers ParisTech, LAMPA, 2 bd du Ronceray, 49035 Angers Cedex, France \\ ${ }^{2}$ IUT Nantes, IRCCyN, 2 av. du Professeur Jean Rouxel 44475 Carqefou, France \\ ayessine.ayed@ensam.eu, bguenael.germain@ensam.eu, camine.ammar@ensam.eu, \\ dbenoit.furet@univ-nantes.fr.
}

Keywords: Water jet assisted machining, Wear, EDS, tool life, titanium alloy

\begin{abstract}
The article presents the results of an experimental study on titanium alloy Ti17. The purpose of this study is to determine the degradation mechanisms of an uncoated carbide tool. Two conditions, roughing and finishing, have been studied under different lubrication conditions. The tests are accompanied by measurement of the cutting forces, the observation of the phenomena of wear (flank, crater, and notch) and EDS analysis. The results showed that the wear mechanisms with and without high pressure water jet assistance are not identical. Indeed, in the roughing condition and in conventional machining, tool deforms plastically and eventually collapses quickly because the temperature in the cutting zone becomes too high. In contrast, this problem disappears under water jet assisted machining and the flank wear is stabilized. Tool life is greatly increased but its sudden rupture is due to the propagation of notch.
\end{abstract}

\section{Introduction.}

Titanium alloys are known for their excellent mechanical properties, low density, and good corrosion resistance. Although they present many advantages for different applications, these alloys raise problems for machining as cutting conditions, namely the cutting speed and feed rate, are limited. Indeed, the machining of these alloys leads to a very important release of heat and high cutting forces that cause a rapid wear of the tool. To cope with these problems, various types of machining assistance are developed. In this study, we are interested in high pressure water jet assisted machining. This type of assistance consists in projecting a high pressure water jet between the rake face of the tool and the chip. The efficiency of the process depends on the choice of the operating parameters of machining and water jet.

Numerous studies have been conducted on the wear of carbide tools, especially in the context of machining titanium alloys and nickel-based alloys. According to the study of Hartung et al [1] tungsten carbide WC is the best material for machining titanium alloys after polycrystalline diamond (PCD). With these tools, a stable layer of titanium is formed between the rake face of the tool and the chip, one that protects against crater wear. The author insists that the wear mechanisms of titanium alloys differ from those of steel or Inconel. The work done by Venugopal et al [2-3] also proves that the uncoated carbide WC / Co presents the best solution for the machining of titanium alloys. The most important wear mechanisms in this case are adhesion, diffusion and plastic deformation of the cutting edge. Other studies on the wear under high pressure water jet assistance show a remarkable increase in the tool life. Indeed Machado et al [4] noted an increase of $300 \%$ of tool life during machining Ti6-Al-4V. Ezugwu et al [5] noticed an increase of $460 \%$ and $740 \%$ respectively when machining Inconel 718. Braham-Bouchnack et al [6] observed an increase of $185 \%$ during the machining of Ti555-3. However, no specific mechanisms of wear under high pressure water jet machining were listed by the authors. This study aims to complement previous studies by contributing to the understanding of wear mechanisms in conventional lubrication and high pressure water jet assistance. 


\section{Experimental setup}

The machine used in these tests is a LEADAWELL LTC25iL lathe with a maximum power of 24 $\mathrm{kW}$. Force measurement is performed by means of a dynamometer type Kistler 9257B. Wear measurement is provided by a binocular microscope and a scanning electron microscope. Additional analyses were performed by EDS to identify visible deposits on the cutting zone of the tool. Three configurations of lubrication (conventional lubrication and high pressure assistance 100 bar to 250 bar) and two cutting conditions (roughing and finishing) were tested.

The parameters used for the two conditions are given in Table 1:

Table 1. Cutting parameters

\begin{tabular}{lcc} 
& roughing & finishing \\
\hline Cutting speed, Vc (m/min) & 50 & 50 \\
Feed, f(mm/rev) & 0.3 & 0.1 \\
Cut depth, ap (mm) & 3 & 1.5 \\
\hline
\end{tabular}

The tool used is type $\mathrm{C}\left(80^{\circ}\right.$ rhombic) with an uncoated carbide grade H13A WC / Co. This type of carbides is recommended for machining titanium alloys. Table 2 shows the geometrical characteristics of the tool.

Table 2. Geometrical parameters of the tool

\begin{tabular}{|l|c|}
\hline Geometrical parameters & Values \\
\hline Nose radius $(\mathrm{mm})$ & 1.2 \\
\hline Edge radius $(\mu \mathrm{m})$ & 30 \\
\hline Rake angle $\left(^{\circ}\right)$ & 7 \\
\hline Flank angle $\left(^{\circ}\right)$ & 6 \\
\hline Inclination angle $\left(^{\circ}\right)$ & -6 \\
\hline Cutting edge angle $\left(^{\circ}\right)$ & 95 \\
\hline
\end{tabular}

\section{Results of the finishing tests}

The finishing tests are performed over a span of 20 minutes maximum. Fig. 1 shows the evolution of flank wear for the three lubrication conditions. After 15 min of machining, wear does not exceed $0.13 \mathrm{~mm}$ for the three configurations.

In conventional lubrication after the running-in phase, flank wear (VB) evolves linearly to $0.13 \mathrm{~mm}$ after $15 \mathrm{~min}$. However, under high pressure water jet and after the running-in phase, flank wear remains stable over a significant period. After this step, the VB begins to increase in a manner similar to that observed in conventional lubrication. In both high-pressure lubrication conditions, the flank wear is about $0.1 \mathrm{~mm}$ after $15 \mathrm{~min}$ of machining.

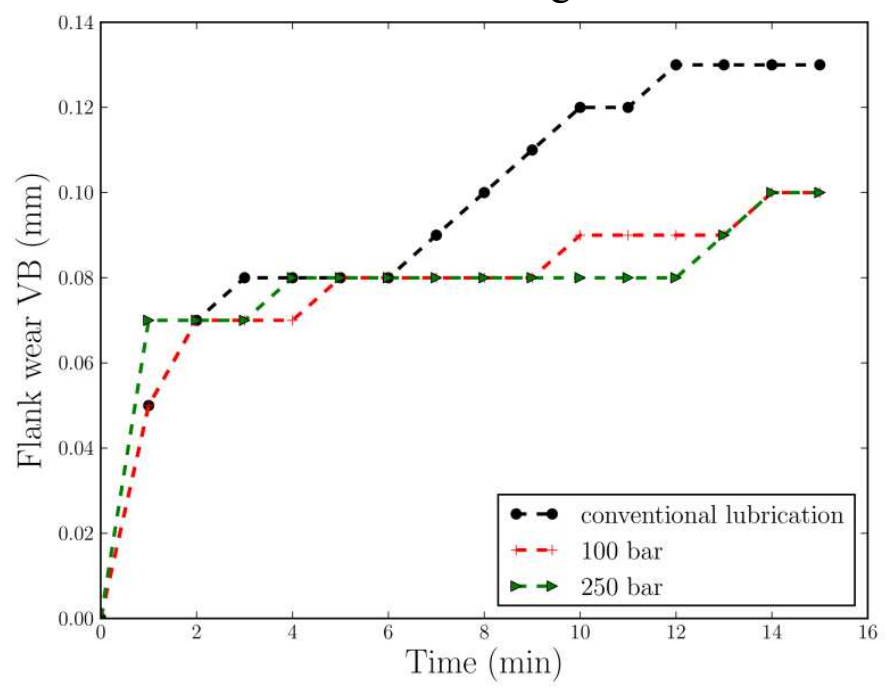

Fig. 1. Evolution of the flank wear 
Figure Fig. 2 (a) shows the rake face and the flank face of a tool after a conventional machining of $20 \mathrm{~min}$. Deposit layers of material adhering to the cutting face of the tool are clearly visible. The existence of such layers can be explained by the high temperature in the cutting area, which results in the adhesion and bonding of the material on the tool. During the machining phase/process, these layers protect the tool against different wear types, Fig. 2 (b) shows traces of abrasion on the coating layer formed on the tool. The rake face does not present a significant crater wear. After some time, however, the adhering layers become unstable and come off by pulling the tool material.
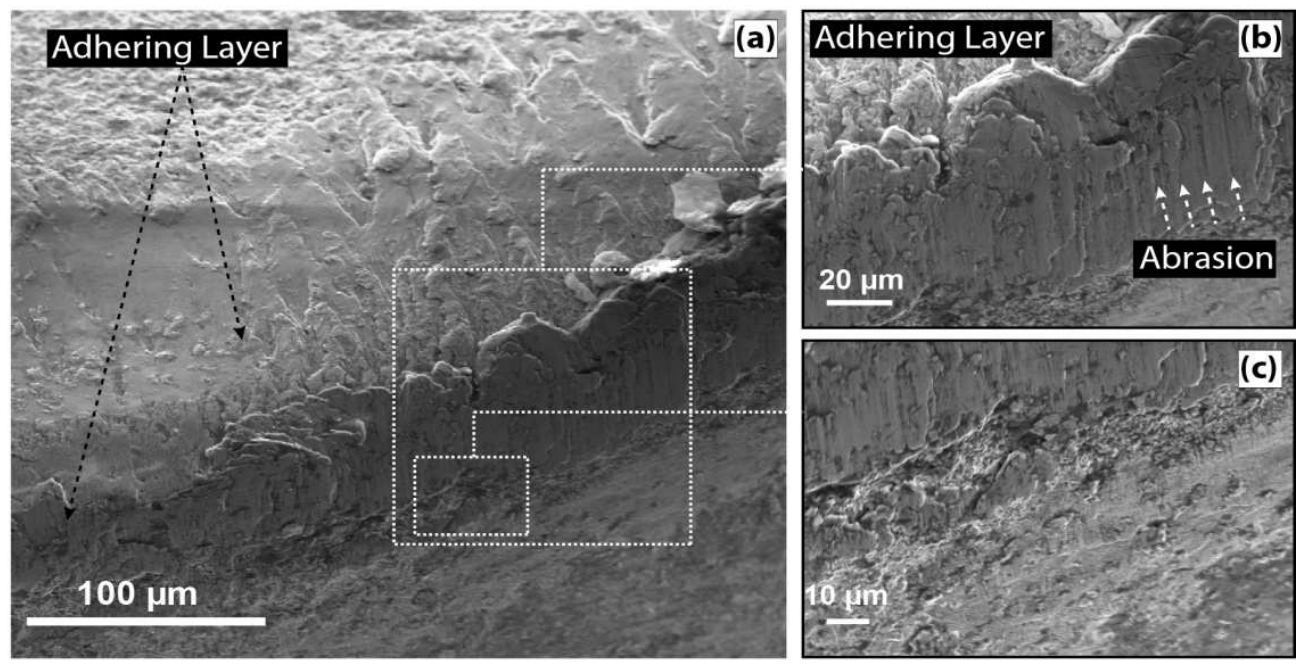

Fig. 2. (a) Rake and flank faces, (b) Adhering layers on the flank face, (c) Flank wear

In the case of high pressure water jet assisted machining; the same mechanism of wear is noticed. By contrast, the water jet removes the adhering layers formed leading to an acceleration of the breakout area. Thus, the adhesive wear is more important. Moreover, the rake face is no more protected by the layers of deposits, which also increases the wear by abrasion and erosion. Fig. 3 illustrates these findings with the observation of a crater formed after 20 min of machining under a pressure of 250 bars.

Under these conditions, the thermal effects are greatly reduced [7], the wear mechanisms of thermal origins like diffusion and, especially, the plastic deformation, are not dominant. The main mechanism of wear in this case is the adhesive wear followed by abrasion and erosion. These findings confirm the results of other studies on the adhesive wear of nickel-based alloys made by Devillez et al [8], Bhatt et al [9] and Xue et al. [10]

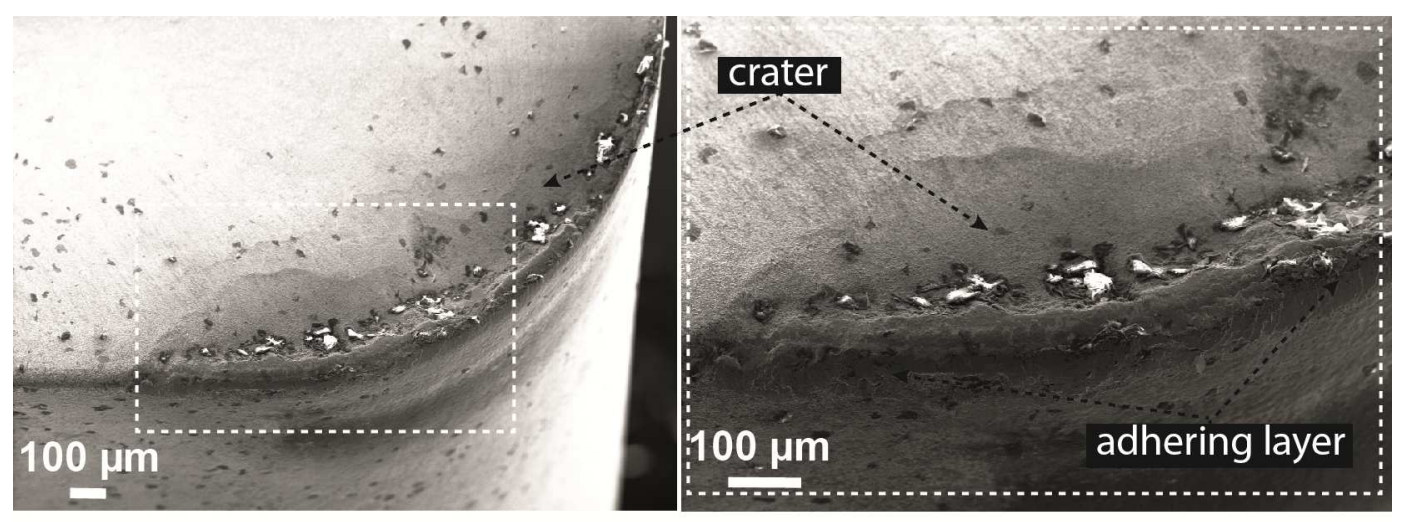

Fig. 3. Crater wear under high pressure water assistance ( $\mathrm{P}=250$ bar $)$ 


\section{Results of the Roughing tests}

The roughing tests were conducted in the same manner as the finishing tests; the maximum duration of the tests is set at $5 \mathrm{~min}$.

In the case of conventional lubrication, the cutting edge collapses just after machining time of $75 \mathrm{~s}$. The collapse of the edge is caused by severe plastic deformation wear. Indeed, the temperature at the cutting edge is very high, which causes the thermal softening of the tool. Cutting forces remain high and exceed $1900 \mathrm{~N}$; the cutting edge begins to deform plastically and eventually collapses. Fig 4 (a) shows the rake face of a tool after $60 \mathrm{sec}$ of machining under conventional lubrication. Plastic deformation of the edge and significant flank wear that exceeds $0.6 \mathrm{~mm}$ is visible.

At the pressure of 100 bars, a notch at the depth of cut and a crater on the rake face are visible. Fig. 4 (b) shows the notch and the crater formed after 5 min of machining.

The mechanism of notch wear is detailed by Xue et al. [10]. Indeed, the deposits of material stick and intersperse in the notch. During machining, these layers quickly become unstable and detached from the tool surface, thereby tearing carbide grains. As for crater wear, the action of the water jet loosens deposits formed more frequently, which accelerates wear by adhesion and thus the formation of the notch.

At the pressure of 250 bars, the evolution of the notch wear is low. By contrast, the crater is relatively large. The high pressure water jet probably prevents the evolution of the notch by acting as a protection from adhesion at the depth of the cut. But this cannot be observed on the cut surface when crater wear is more pronounced.

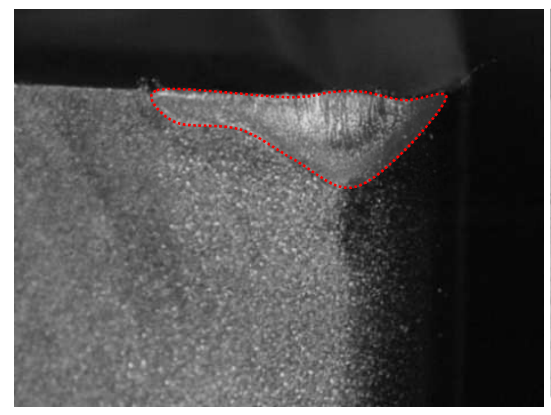

(a)

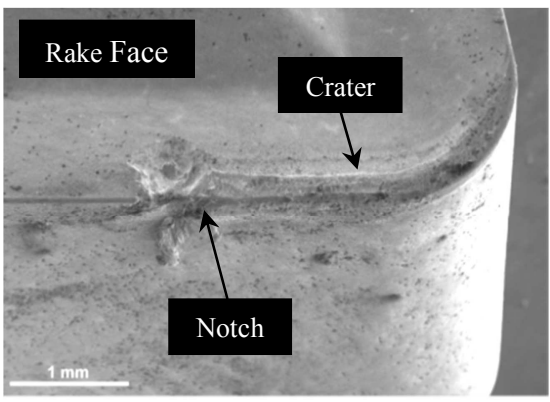

(b)

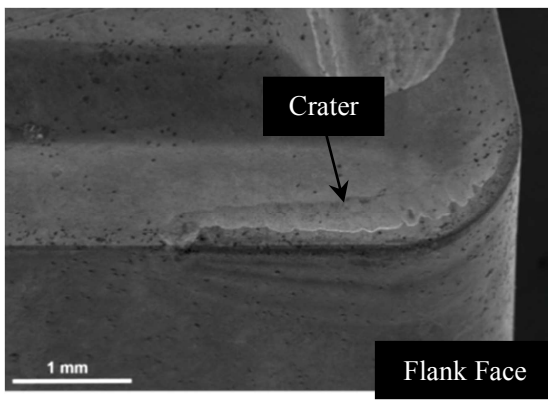

(c)

Fig. 4. (a) Conventional lubrication, (b) 100 bar, (c) 250 bar

For tests under high pressure water jet, other wear mechanisms are activated, particularly, adhesive wear. With high pressure water jet assistance, lifetime is significantly increased. In fact, after $5 \mathrm{~min}$ machining, flank wear does not exceed $0.24 \mathrm{~mm}$ at 250 bars. Figure 5 shows that water jet assisted machining can increase tool life by about four times.

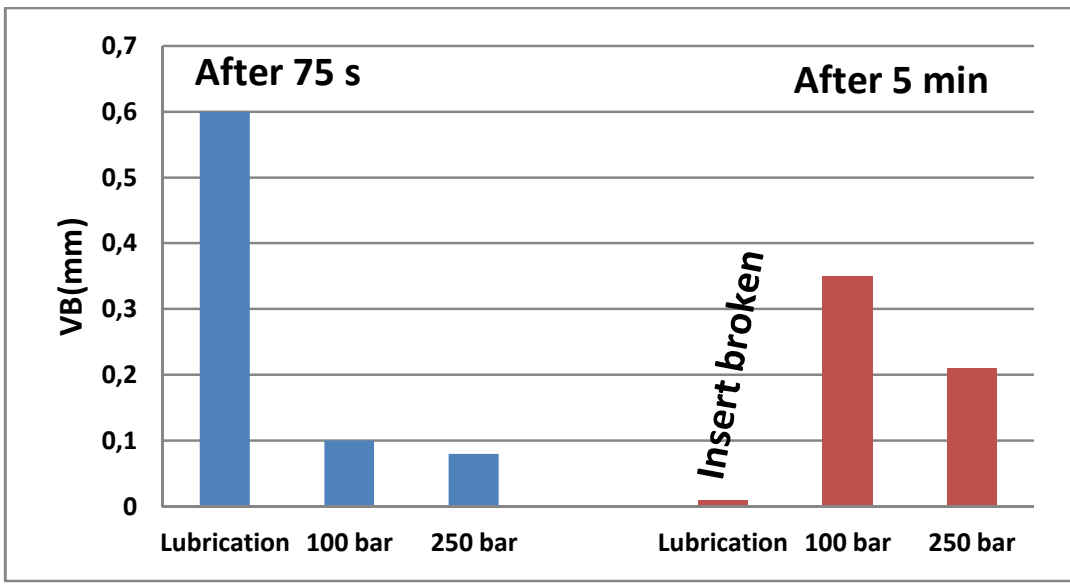

Fig. 5. Flank wear 


\section{EDS analysis}

In this study, EDS technique was used to analyze the deposits on the surface of the tool. EDS analysis shows the areas of titanium deposits and eroded areas on the tool rake face. For example, Fig. 6 shows the zones at the rake face in the case of finishing machining at the pressure of 100 bars.

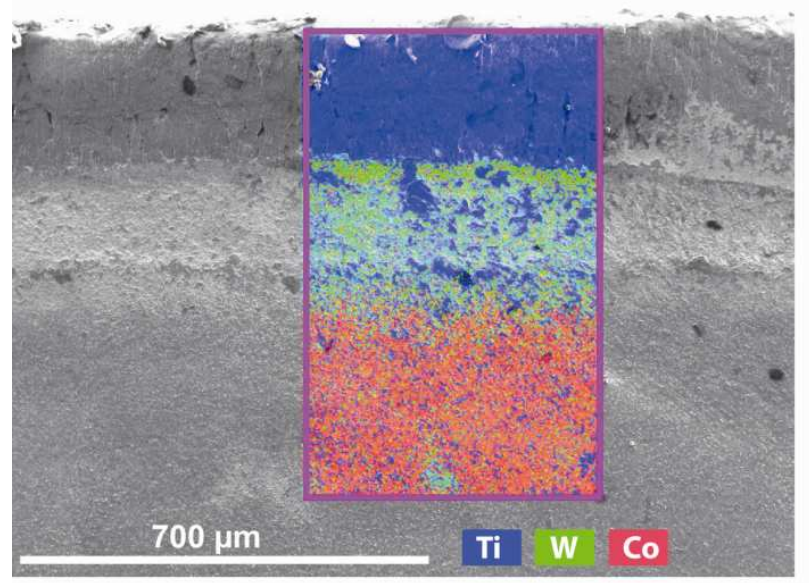

Fig. 6. EDS analysis on the surface of the tool

This analysis shows that the abundance of the titanium alloy elements decreases with the growing pressure of the water jet. This result proves that the water jet plucks titanium deposits from the tool surface.

In addition, the width of the area which is rich in titanium makes it possible to determine the length of the contact chip / tool. Results show that the length of the contact chip / tool decreases with the increasing pressure of the jet support. For testing, finish is estimated at respectively 180 microns, 109 microns, and 74 microns for conventional lubrication, high pressure water jet at 100 bars, and 250 bars.

\section{Conclusion}

The study allowed us to understand some of the mechanisms of carbide tool degradation under conventional lubrication and under high pressure water jet assistance. Whether for configuring roughing or finishing, high pressure water jet assistance can significantly increase the tool life.

Indeed, for the finishing condition the dominant wear mechanisms are:

- For conventional machining: flank wear by abrasion,

- High pressure water jet assistance: adhesion wear followed by abrasion and erosion at the rake face (crater).

After $15 \mathrm{~min}$ of machining, the flank wear of $0.13 \mathrm{~mm}$ with conventional lubrication is reduced to only $0.1 \mathrm{~mm}$ with water jet pressure assistance.

For the roughing condition, the dominant wear mechanisms are:

- For conventional machining: the tool collapses through plastic deformation.

- High pressure water jet (100 bars): notch wear and crater are important.

- High pressure water jet (250 bars): low evolution of notch wear. Only the crater wear is important.

\section{Acknowledgment}

Authors would like to thank « Région des pays de la loire » for funding of the project which is part of a $\mathrm{PhD}$ thesis 


\section{Références}

[1] Hartung, P., Kramer, B. et von Turkovich, B. (1982). Tool wear in titanium machining. CIRP Annals - Manufacturing Technology, 31(1):75 - 80.

[2] Venugopal, K., Paul, S. et Chattopadhyay, A. (2007a). Growth of tool wear in turning of ti-6al$4 \mathrm{v}$ alloy under cryogenic cooling. Wear, 262(9-10):1071 - 1078.

[3] Venugopal, K., Paul, S. et Chattopadhyay, A. (2007b). Tool wear in cryogenic turning of ti-6al$4 \mathrm{v}$ alloy. Cryogenics, 47(1):12 - 18.

[4] Machado, A., Wallbank, J., Pashby, I. et Ezugwu, E. (1998). Tool performance and chip control when machining ti6al4v and inconel901 using high pressure coolant supply. Machining Science and Technology, pages $1-12$.

[5] Ezugwu, E. et Bonney, J. (2004). Effect of high-pressure coolant supply when machining nickel-base inconel 718, alloy with coated carbide tools. Journal of Materials Processing Technology, pages 1045-1050.

[6] Bouchnak, T. B. (2010). Etude du comportement en sollicitations extrêmes et de l'usinabilité d'un nouvel alliage de titane aeronautique : le Ti55-3. Thèse de doctorat, Arts et Métiers Paristech.

[7] Hong, S. Y. et Ding, Y. (2001). Cooling approaches and cutting temperatures in cryogenic machining of ti-6al-4v. International Journal of Machine Tools and Manufacture, 41(10):1417 1437.

[8] Devillez, A., Schneider, F., Dominiak, S., Dudzinski, D. et Larrouquere, D. (2007). Cutting forces and wear in dry machining of inconel 718 with coated carbide tools. Wear, 262(7-8):931 942.

[9] Bhatt, A., Attia, H., Vargas, R. et Thomson, V. (2010). Wear mechanisms of wc coated and uncoated tools in finish turning of inconel 718. Tribology International, 43(5-6):1113 - 1121.16 [10] Xue, C. et Chen, W. (2011). Adhering layer formation and its effect on the wear of coated carbide tools during turning of a nickel-based alloy. Wear, 270(11-12):895 - 902. 